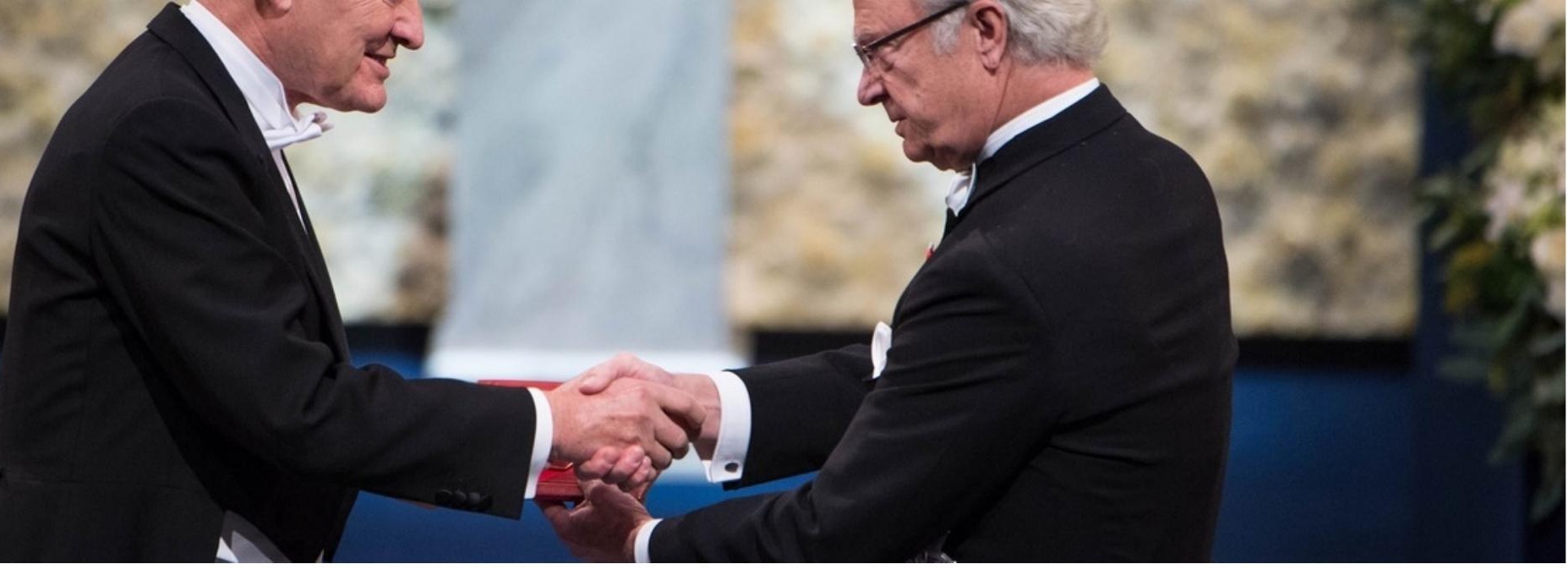

Abstract:

\title{
My early Werdegang in Science: Reflections of a Nobel Laureate
}

\author{
Authors: Joachim Frank \\ Submitted: 26. May 2021 \\ Published: $\quad 31$. May 2021 \\ Volume: 8 \\ Issue: 3 \\ Affiliation: Columbia University, New York, USA \\ Languages: \\ Keywords: \\ Categories: \\ DOI: \\ English \\ Science, Nobel Prize, Campus, Future \\ Humanities, Social Sciences and Law \\ 10.17160/josha.8.3.760
}

In this article by Nobel Prize winner Dr. Joachim Frank he allows deep insights in his "Werdegang of Science" at the speech on May 1, 2021 at the Science Gala of the German International School New York (GISNY). Dr. Michael Teufel, president of the school's board, invited him to say a few words at the Gala whose purpose was to raise funds for the next step of a visionary program entitled "Campus of the Future." CNobel Media AB 2017, photo: Pi Frisk

\section{JOSHA Joumana ossinese Humanities and Arts}




\section{My Early Werdegang in Science: Reflections of a Nobel Laureate}

Speech given on the occasion of the May 1, 2021 Science Gala of the German International School New York

First the context:

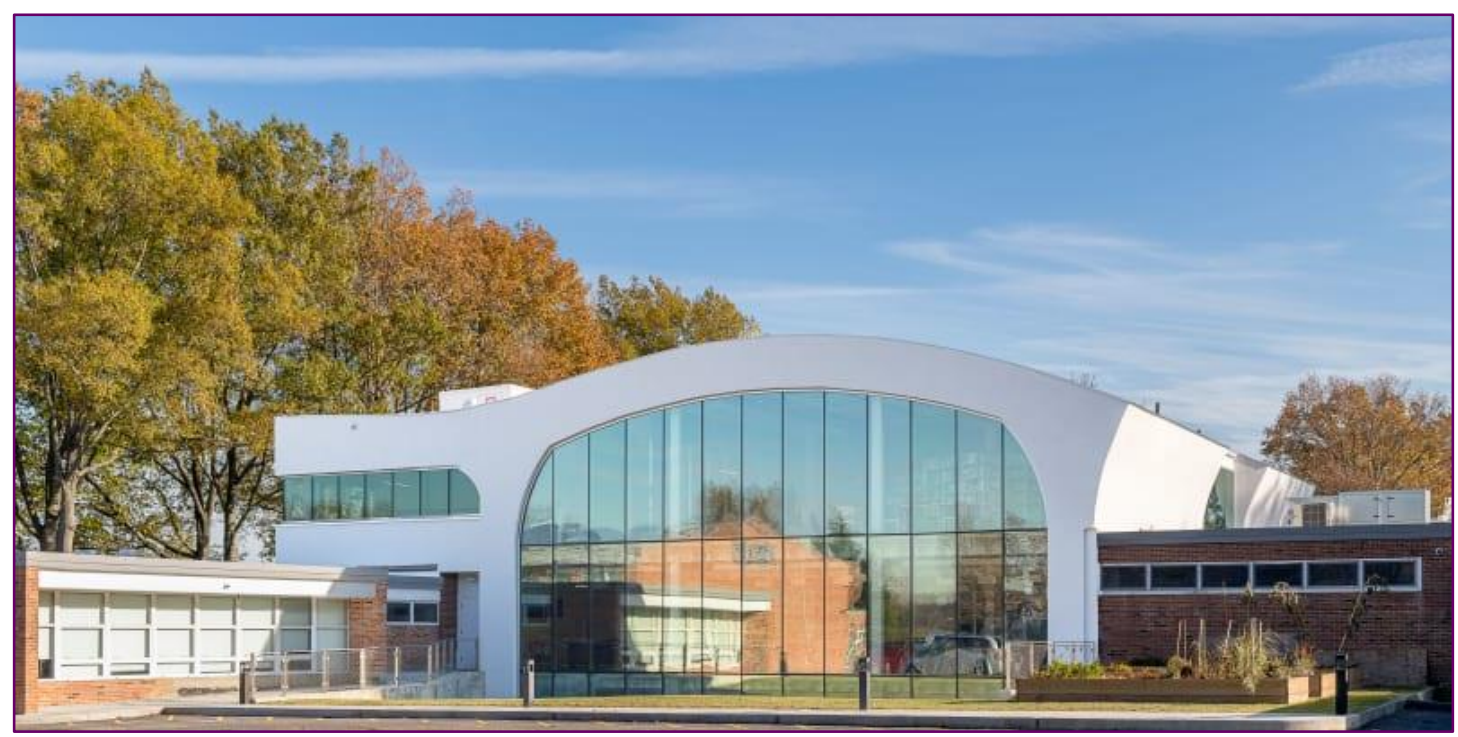

GISNY, the German International School in New York, is located in White Plains, just 25 miles north of New York City. It is part of a network of over 140 German schools around the world, providing an academically outstanding bilingual education in science, foreign languages and the arts. It is funded, in part, by the German Foreign Service. Current enrollment is 400 students in Pre-K through Grade 12.

The school's website says, "most students are from German-speaking countries and may have lived in several countries before coming to New York. $A$ growing number of our students were either born in the United States or have lived the majority of their lives in the US. GISNY students speak a variety of languages with their families at home, including but not limited to German, English, French, 
Italian, Spanish, Japanese, Arabic, Tagalog and Thai." The faculty has over 50 members, 95\% of whom hold advanced degrees (Master of Art or European equivalent). Languages taught are German, English, Spanish, French and Latin.

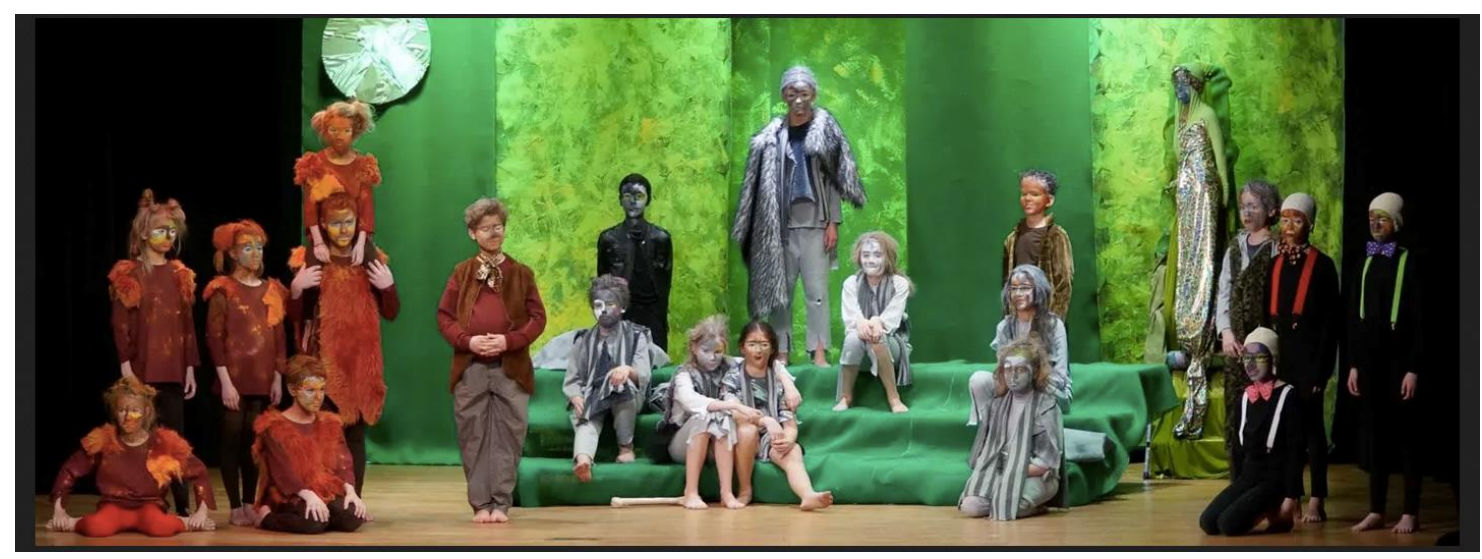

Dr. Michael Teufel, president of the school's board, invited me to say a few words at the May 1, 2021 online Gala whose purpose was to raise funds for the next step of a visionary program entitled "Campus of the Future." I quote from the program booklet issued on that occasion:

"In September 2018, GISNY started the "Campus of the Future" with the reenvisioning and expanding of the school. A number of classrooms were reconceived and added along with a cafeteria, student lounge, faculty room, head of school offices. The Science Wing Project is the next phase in the development of the "Campus of the Future" by taking a new approach to all the science classrooms and by adding a new maker space. This is not a remodeling initiative but rather an entirely new design that will allow an already strong science curriculum to undertake an approach to studying science that incorporates cutting-edge technology in ways that are currently not possible." 
Dear President Dr.Teufel, dear Alumni, dear parents, dear students!

First of all my congratulations on the substantial expansion and enrichment of your science program that we all celebrate tonight! May the new facilities in the Science Wing of your school motivate and inspire a new generation of future scientists at an early stage! Confronted with unprecedented problems the planet faces, we do need a new generation of scientists with brand-new, creative ideas.

On this very special occasion I was asked to talk about myself since there is a lot of curiosity about how one gets to a place with high recognition in science. Short of giving an exact recipe - there is none as I can assure you! - I can talk about my early steps that biased me toward the natural sciences as a career choice.

I was born in 1940 in Siegen, a small town in the Siegerland, about 100 kilometers due east from Bonn. It is a mountainous area with rough climate, with its own peculiar dialect, and a long history of iron mining and manufacturing going back two thousand years, to the Celts. My father was a judge while my mother whose family had artistic inclinations took care of four children -- me and a brother and two sisters. Our large red brick house was firebombed in February 1944, an event I remember clearly even though I was just three and a half years old. In fact, in all air raids by the Allies during the war, $80 \%$ of my hometown was destroyed because of the strategic importance of iron products. As a time reference for younger people, World War II started on September 1, 1939 with Hitler's invasion of Poland, one year before I was born, and ended on September 2, 1945, exactly six terrible years and one day later.

Growing up among the ruins of houses destroyed in the neighborhood, playing in the rubble that was left, had a morbid fascination to me as a child and other children of my age that is difficult to describe to people who have not been touched by war. I found copper wires, electric switches and fuse boxes made of 
black Bakelite in the damp dirt where nettles and dandelions had taken a foothold. I found a family of mice with several pink babies hidden under heaps of mortar and bricks. I can still remember the smell of decay. This experience would become a lasting influence. We know about the Schmuddelkinder, the kids that grew up in the rubble of post-war Germany, from the anti-bourgeoisie songs of Franz Joseph Degenhardt. I was a very unusual species: a bourgeois variety of the Schmuddelkind.

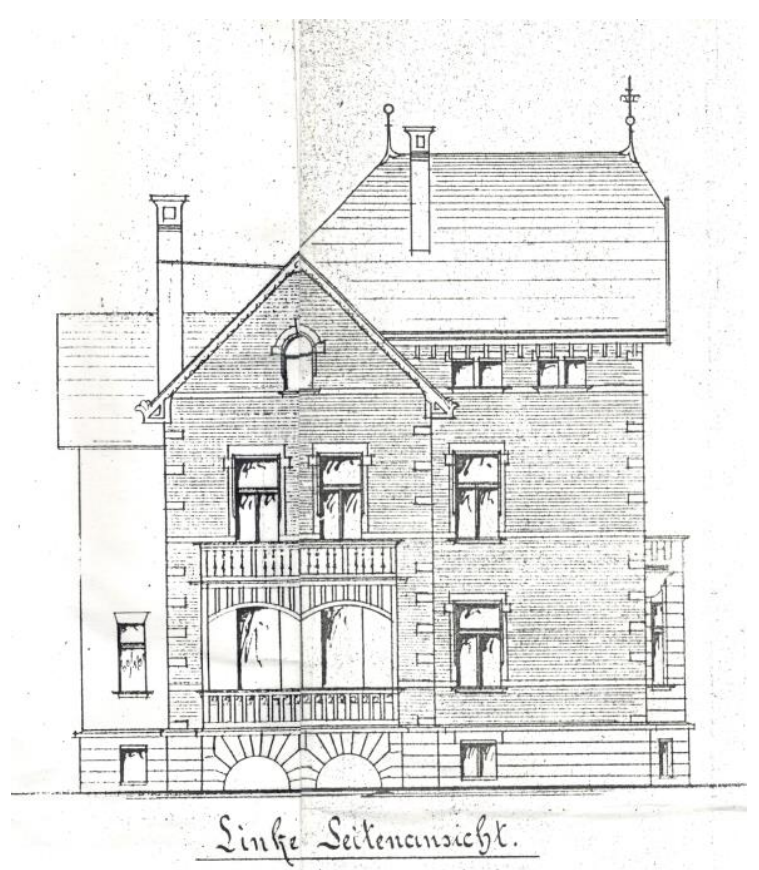

Architectural drawing for my parents' house, built by my grandparents in 1905, shows the verandah. In the space underneath I started my experiments at age eight.

Looking back, I can recognize this as the first time my mind was tempted by the urge to seek explanations for mysterious objects I got my hands on. As an eight year old, I was doing experiments in the space under the verandah of the house I grew up in. I developed the habit of collecting things that had any conceivable use in projects yet to be defined. Little bottles, wires, washers, 
screws, tubes, brackets, magnets -- you name it. I got excited whenever I found two parts independently that turned out to fit together perfectly. I came to do experiments before knowing what science is. I confirmed, by building a little apparatus, that coal when heated up will emanate a flammable gas. I could see with my own eyes how a piece of zinc dissolves in acid without trace. How carbide violently reacts with water and produces a strongly smelling gas. I tried to create invisible ink that would only show up when the paper was heated. I discovered a large bunch of cherry tree seedlings in the compost, and made posters trying to sell them for five pennies a piece. There were no takers, unfortunately.

Later I started tinkering with radio parts. My elder brother showed me how to build a primitive tunable crystal radio. In the Gymnasium in sixth grade I made friends with a boy who was similarly taken by electric circuits. Together we spent our free time in the attic with valves, yards and yards of insulated copper wire, transformers, resistors, and capacitors. I built several compact AFM radios into soapboxes. I spent all my pocket money on mail orders for electronic parts. At the time I actually had dreams about walking into a warehouse full of these beautiful, shiny, exact objects, and being able to take what I wanted.

Writing this down suddenly made me realize the connection between my solitary tinkering in childhood and the Makerspace concept where students are encouraged to dream up designs and realize them, working in teams of tinkerers and using a large variety of objects hoarded, found, or supplied by the school. Looking up "Makerspace" in the Wikipedia I was redirected to Hackerspace, a German invention in the 1990s that slowly spread across the world. If it is true that my later interest and success in science goes all the way back to the time I spent with experiments under the verandah, then it is quite likely that the new Makerspace in your Science Wing will be a perfect catalyst for creativity in science in your later life. 
Up to the point when I was perhaps 12 years old I was driven by native curiosity, before getting any formal science education or inspiration from school. But at home my parents provided a thoroughly intellectually stimulating and nurturing environment. In that vein I should also mention the lasting influence of Meyer's Konversationslexikon, a twenty-volume encyclopedia that my grandparents had bought in 1905, about a thousand pages each. I spent hours and hours in the living room skimming through the entire world of knowledge accumulated through 1905.

This changed quite a bit when I advanced to the high school level in the Gymnasium, when my class got a physics teacher who was truly inspiring. It was physics, not biology or chemistry, that carried my interest. This is quite ironic, given the fact that later, after my training in physics, I worked on problems in biology, and in the end received a Nobel Prize in chemistry.
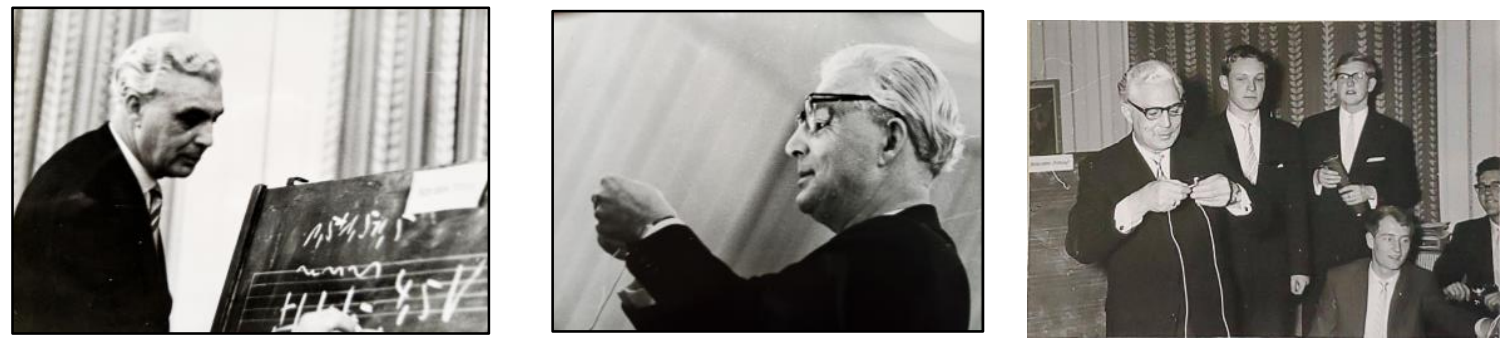

Der Schöne Willy

$3^{\text {rd }}$ image: "My physics teacher Willy Schröder standing next to me as he successfully put an electric circuit together from a little flashlight bulb, two pieces of wire, and a battery. The picture was taken during the Abitur graduation party as we gave mock exams to our teachers. (The photo was digitally enhanced)."

But back to my physics teacher, whose name was Willy Schröder. We called him Der Schöne Willy since he kept his hair meticulously styled in waves with the aid of pomenade. Later in college, unwittingly, I associated his name with the wave equations of his almost-namesake Schrödinger. Schröder had an infectious enthusiasm, setting up for effect large experiments that involved electric discharges and lots of noise. Of all classes, I liked most his advanced-level workshops I had signed up for, along with four other students. When it came to a decision on what to study at the university, my mind was made up early on. Only 
my father needed a lot of convincing since he was skeptical a degree in physics would be a bread-winning prospect.

So if you ask me how to get started on a successful career in science, I come up with quite a jumble of a shopping list: there are fortuitous circumstances outside of anybody's control, like the opportunity to play in the rubble of ruins nearby; there are parents who encourage you in your creative quests; there are dedicated, inspiring teachers who are able to strike a spark; there is certainly a lot of hard work; there is also what I call peripheral vision: keeping your eyes open for things that come out of left field. And last but not least there is a good deal of luck.

Let me finish with one thought prompted by the new reality we live in after a year of pandemics: the practices and methods of science know no borders. I found that one of the most satisfying and exhilarating aspects of my life in science has been finding kindred spirits and making friends with collaborators worldwide. In fact, the speed with which vaccinations have been developed last year is a success story that highlights the importance and efficiency of international scientific collaborations. In my work over the years I have collaborated with inspired scientists from Argentina, Czech Republic, China, England, France, Germany, Italy, Russia and Spain. Visits to their labs and meeting them at international conferences continued to open up my horizon not just in science but in all aspects of humanity. If you choose to become a scientist, then you will become a Weltbürger - a world citizen -- in a true sense. This alone makes science an exciting and rewarding career choice. 


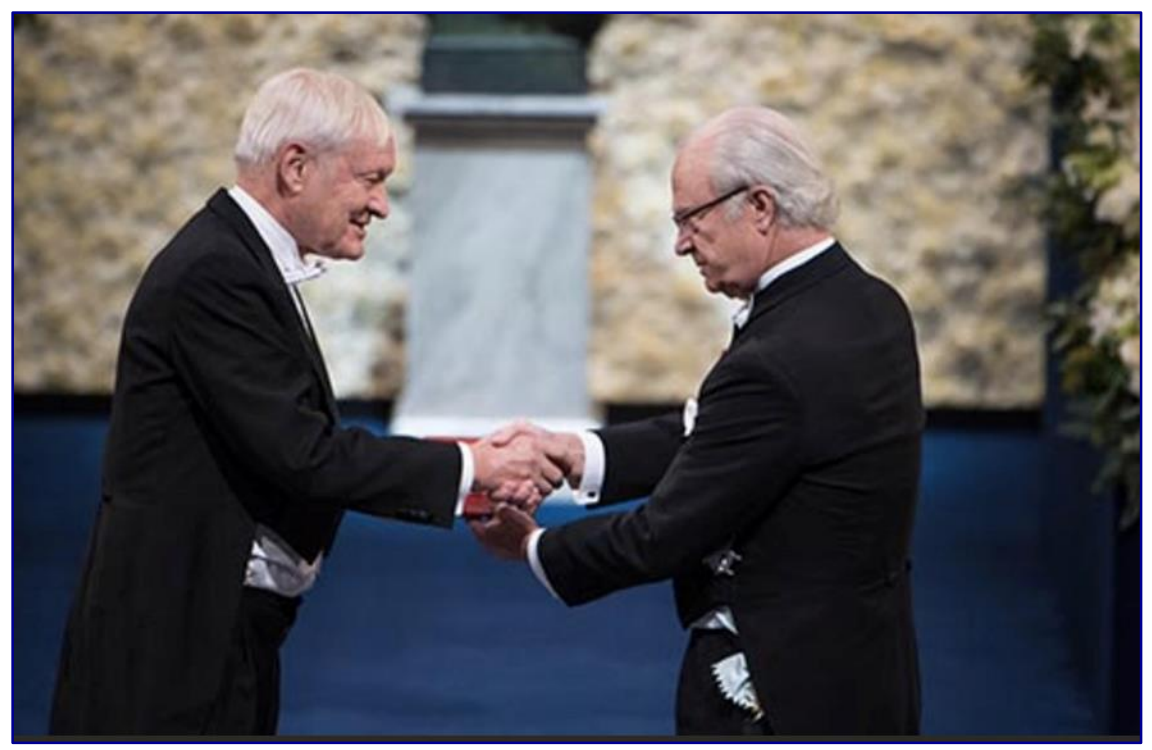

Ceremony with the Swedish King in Stockholm on December 10, 2017 CNobel Media AB 2017, photo: Pi Frisk

\section{Acknowledgment:}

I thank Thomas Murphy for digital enhancement of one of the photographs 
About the author:

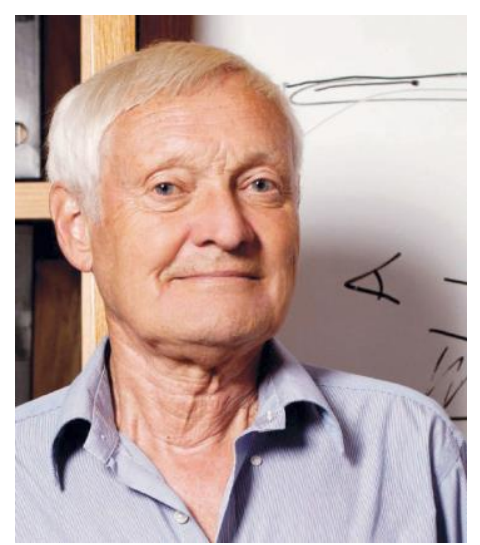

Photo Credit: Jörg Meyer

\section{Joachim Frank}

Joachim Frank is a Professor of the Department of Biochemistry and Molecular Biophysics, and the Department of Biological Sciences at Columbia University. He studied Physics at the University of Freiburg and received his Ph.D. from the Technical University in Munich. In 1975 he joined the Wadsworth Center in Albany as a Senior Research Scientist. In 1985, he joined the faculty of the Department of Biomedical Sciences of SUNY Albany. In 2008 he moved to New York to assume his current position. Dr. Frank's lab has developed techniques of singleparticle reconstruction of biological macromolecules using the electron microscope, specializing in mathematical and computational approaches. He has applied these techniques of visualization to explore the structure and dynamics of the ribosome during the process of protein synthesis. They are now widely used to study the structure of the COVID-19 virus and other pathogens and biomolecules implicated in human diseases.

Dr. Frank is a member of the National Academy of Sciences and of the American Academy of Microbiology. He is also a fellow of the American Academy of Arts and Sciences and of the American Association for the Advancement of Science. In 2014 he was honored with the Franklin Medal for Life Science. In 2017 he shared the Wiley Prize in Biomedical Sciences with Richard Henderson and Marin van Heel. He was awarded the 2017 Nobel Prize in Chemistry together with Jacques Dubochet and Richard Henderson. 